\author{
Драгана Ђурић \\ Балканолошки институт САНУ \\ draganasdjuric@gmail.com \\ Dragana Djurić \\ Institute for Balkan Studies SASA \\ draganasdjuric@gmail.com
}

\title{
НАЗИВИ ПОКОЈНИКА КОД СЛОВЕНСКИХ НАРОДА
}

\section{TERMS FOR THE DECEASED AMONG SLAVIC PEOPLES}

У раду се анализирају различити називи за покојнике код Словена. Полази се од анализе најстарије забележених назива с кореном *mr-/ *mer- i *nav-. Потом се анализирају табу називи — њихова мотивација и функција у посмртним обредима и народној култури уопште. У посебну групу су издвојени називи покојника који нису умрли „својом“ (природном) смрћу, већ на други начин (иооиинули, самоубице, обещеюьаии, уйойьеници, итд.).

Кључне речи: смрт, називи покојника, посмртни обреди, Словени.

The paper analyses different terms for the deceased among the Slavs. It starts with the analysis of the oldest recorded terms with the root *mr- /*mer- and *nav-, continues on to different regional terms. Next it analyses taboo terms, their motivation and function in posthumous rites and folk culture in general. The terms for the deceased who did not die of natural causes, but rather died in other ways (killed, suicide, hung, drowned) are grouped separately.

Key words: death, terms for the deceased, posthumous rites, Slavs.

\section{Уводна размайрања}

Посмртни обреди се код свих словенских народа одликују врло архаичним цртама, будући да су најуже везани за смрт и онострано. Смрт неког члана породице је, између осталог, схватана као тренутак који је опасан за све који остварују контакт са покојником, посебно уколико је умро „неприродном“, односно насилном и прераном смрћу. Покојници који су, према народном схватању, били грешни, који су завршили живот погибијом, самоубиством или су умрли у „опасном“ периоду године (нпр. током Тодорове недеље), као и они за које се током њихова живота говорило да су вешци/вештице, сматрани су „нечистим“, и веровало се да су 
посебно опасни и непријатељски настројени према живима (Раденкович 2016: 141). С друге стране, они који су умрли од старости су називани ирецима и веровало се да они, с оноі света, помажу и пазе на своје живе потомке. Ипак, у случају обе групе покојника је био заједнички императив правилног спровођења свих посмртних обредних радњи (од тренутка умирања, онда прања и облачења покојника, бдења, сахрањивања, до повратка с гробља, организовања даће, итд.). Већина ових радњи је посвећена прекидању везе покојника са овим светом, чиме би му био олакшан одлазак на онај свет, а истовремено се обезбеђивала сигурност оних који га испраћају и за њим остају. На пример, уз обавезно „чување“ покојника током ноћи, вршене су одређене радње којима се спречавао, како се веровало, његов повратак у свет живих. Веровало се да се покојник може повампирити, уколико у тело (које је душа напустила) уђе зао или нечисти дух, па су га зато убадали иглом или глоговим коцем у прст, ухо или пупак. Да се не би повампирио, пазило се и да га не прескочи нека животиња (поготову мачка или кокошка) $)^{1}$, па и да се ништа не додаје преко одра. Исто тако, једна од важних забрана се односила на именовање преминулог. Лично име покојника се није смело помињати, због тога што се веровало да би тиме био призван и да би се вратио. Због тога су се најчешће користили „безлични“ колективни називи, затим еуфемистички називи који упућују на субјективне представе говорника о смрти и покојнику, називи којима се говорник штитио од покојника и контакта са оним светом, као и називи који су мотивисани начином на који је неко умро.

У досадашњој научној литератури не постоји рад који за тему има називе покојника код словенских народа. Ови називи су најчешће били у другом плану и помињани су успут, у оквиру радова и монографија посвећених посмртним обредима.

\section{1. Словенски називи за йокојника с кореном *mrt-, *mr-, *mer-, *mor-}

Међу најраспрострањенијим савременим називима за покојника код свих словенских народа се убрајају називи с кореном *mrt-, *mr-, *mer-, *mor- (Жуйкова 1998: 83). Фасмер наводи да је индоевропско *mrtos, које је сродно са староиндијским *mrtas (умрли) и *martas (смрйни, човек), дало у прасловенском *mьrtvъ (Фасмер 1986: 606).

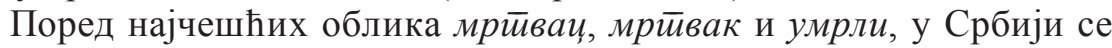

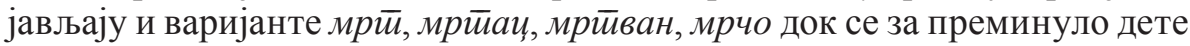
говорило и мрйащиац или мрйваче (Барјактаровић 1985: 170; РСАНУ 1988: 197, 200-202; Ердељановић 1951: 142). С друге стране, деминутивног

1 Уколико нека животиња прескочи одар, у Херцеговини се веровало да ће се душа покојника претворити у ту животињу и у том облику изаћи пред Бога (Братић 1903: 399). 
и хипокористичког значења мриивачић означава пиле које је угинуло у јајету: „Кад се који сахрани, при повратку са гробља многи умачу прсте у алену (црвену) боју, те да после при насађивању живине не би било мртвачића“ (РСАНУ 1988: 202). У околини Бјеловара се говорило и да у кући где је мрйвик није добро да буду мачка, пас или живина, зато што би исте године могао умрети још неко из те куће (РСАНУ 1988: 203). У Височкој нахији се код католика употребљавао и назив мри: „Људи и жене из села долазе да виде мрца““ (Филиповић 1949: 181). У Црној Гори се овај назив користио и у погрдном значењу, као критика флегматичном ставу, успорености, лењости: „Ајде, мрцу један“ (Станић 1990: 467). На истој територији су слабашну женску (ређе мушку) особу, која је и трома или лења,

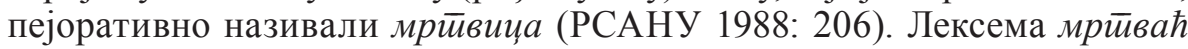
такође има пејоративно значење „тром, неагилан човек, слабић, кукавица“ (РСАНУ 1988: 201). У Лужници и Нишави се покојник називао мртиаваи (Николић 1910: 256), као и у Скопској Црној Гори: „Кад мртавац мора да преноћи код куће, покрију га сертмом (мрежом, којом се риба лови) да не би још ко умро, и да се не би он повампирио“ (Петровић 1907: 480).

У Бугарској се, такође, јављају називи мъриивеи, мърйавецъ, умирачка (БЕР 1995: 421; Захариев 1918: 139), као и у Словенији mrtvac, mrtvec, umrli, mrlič (БEP 1995: 421; Gliha Komac 2014: 67).

У руском се покојник именује и као мериивеи, мериивель, мериивень,

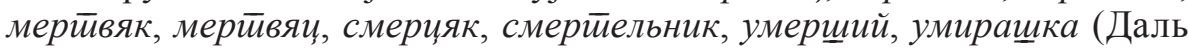
1979: 320; БЕР 1995: 421; Седакова 2004: 127, 231; Власова 2018: 425). Притом, повампирени покојник је неретко именован као мериияяк, смерияк, смериеленик. У белоруском и украјинском се јављају слични називи: мреи, мерлець (Седакова 2004: 127) и мэри, мерлеи, мери, вмериь (Седакова 2004: 127, 215, 223), као и у чешком: mrtvola, mrtvec, mrtvý, umrlec, zетřelý (Седакова 2004: 127; БЕР 1995: 421; Brouček S, Jeřábek R (red.) 2007: 583; Brouček S, Jeřábek R (red.) 2007: 619; Machek 1957: 311) и пољском martwiec (БEP 1995: 421).

\section{2. Словенски називи за йокојника с кореном *nаvь-}

У Слову Григорија Богослова против паганства (1089. година) наводи се да се људи моле Сварожићу и навима топе бању: „И огневи Сварожицю молятся и навьмь мъвъ творять“ (СРЯ 1983: 45). Такође, према летописном сведочанству, епидемија чуме (куге) у Полоцку (1092. године) је приписивана доласку покојника - нава. Казујући о појави невидљивих бесова, који су јуришали на коњима и плашили Полочане до смрти, летописац додаје да су људи тада говорили: „Яко навье бьют полочаны“, односно да мртви кажњавају људе кугом (ПВЛ 1950: 141).

Према староруским писаним споменицима из XIII и XIV века, људи су припремали бању (парно купатило) за покојнике у Чисти четвртак. 
Овог дана су мртвима у бањи остављали и храну (месо, млеко, јаја), посипали по поду пепео (да би видели трагове покојника), качили пешкире да би покојници (нави) могли да се обришу и говорили су: „Мойтесь“ (Mujūe ce). Пошто би сутрадан видели у пепелу трагове сличне птичјим, казивали су: „Приходили к намь навья мытся!“ (Долазили су нам нави gа се мију) (Гальковский 1916: 202).

У Лаврентијевском летопису (XIV век) се наводи како се Ана, кћерка кијевског кнеза Всеволода, вратила из Грчке у Кијев са митрополитом Јованом (III) Скопчином, који је народу изгледао као нав (мртвац): „Приведе Янка митрополита Іюан(а) скопьчину, его же видъвше людье вси рекоша: се навье (по другому списку мерйвеи) пришель“ (Довеgе Ана Јована Скойчину, вияевщи їа љуgи рекоще: „Нав (иррема друіом иеексииу 'мртиваи') је gощао") (Срезневский 1902: 268). У многим деловима Русије се назив за покојника у облику навье, навь, навьи, навья сачувао све до XIX века (Власова 2018: 444). У народу су били у употреби и старији облици навий и навей, као и дијалекатски навья (ЭССЯ 1997: 50).

По свему судећи, код словенских народа су некада лексеме образоване од корена *navb- имале неутрално значење и њима су се именовали покојници, без обзира на њихов статус, старост или пол, чиме се одсликава и народна представа о безличности и безимености покојника (Седакова 2004: 128): староруски навь (навъ) и навье - иокојник, мрииваи (СРЯ 1983:45); српскохрватски nav - мрйваи (ЭССЯ 1997: 49); словеначки nâv - gyщuа умрлої (ЭССЯ 1997: 49). Може се претпоставити, стога, да је нав код неких словенских народа први еуфемистички назив за покојника, који се користио уместо назива с кореном *mr- / *mrt- / $m e r-/ * m o r-$.

Код Руса је један од задушних дана — понедељак (на југу), односно уторак (у средњем делу земље) Томине недеље - познат и данас као „навий день“ (навски gан, gан мрйвих) (Фасмер 1971: 35). Овим данима људи одлазе на гробље и носе понуде покојницима у виду хране и пића. На југозападу Русије су четвртак Ускршње недеље звали „Навский великдень“ (Навски Ускрс) и „Пасха мертвецов“ (Ускрс йокојника) и веровало се да покојници тада иду у цркву на празничну литургију (Власова 2018: 445).

Лексема náv је у старочешком језику имала и значење ірроб, заі̄poбни свети, ag (ЭССЯ 1997: 49; Machek 1957: 319), док је у словачком њоме означавано место на које одлазе добре душе после смрти (Machek 1957: 319). У старим руским преводима библијских текстова се такође употребљавала и у значењу ада, подземног света, царства мртвих (Власова 2018: 444): „Из навии въскрьсе“ (Из мрёвих васкрсе) (XII-XIII век) (СРЯ 1983: 45).

Известан број научника који су се бавили питањем етимологије претходно наведених лексема њихово порекло види у прасловенском *navb- и, даље, у индоевропском *nāu-s (Фасмер 1971: 35). Узимајући у обзир народна веровања да је онај свет одвојен од света живих неким 
великим воденим пространством преко којег плове душе покојника у лађи, као и да је у прошлости постојала пракса сахрањивања покојника полагањем у чамац, Гаљковски, Иванов, Топоров и Журављов су сматрали да је општесловенско *navb- првобитно имало значење брog, а да се потом,

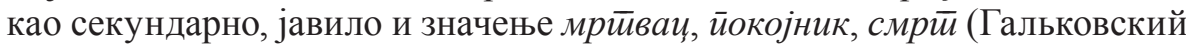
1916: 66; Иванов 1987: 8-9; Иванов, Топоров 1982: 195; Журавлев 2005: 288). Трубачов не сматра да су индоевропско *nāu-s- (броg, чамаu) и *nāu-s-

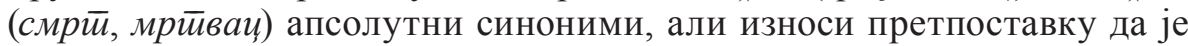
*nāus првобитно могло имати значење „брод мртвих“ (ЭССЯ 1997: 52).

Општесловенско *navb- доводи се у везу и са глаголима *naviti и *nyti

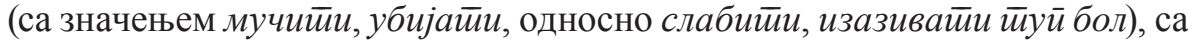

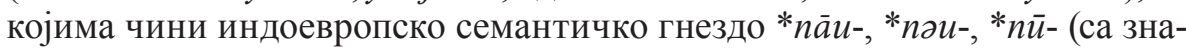

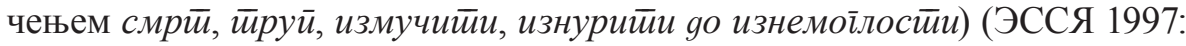
51; Дукова 2015: 65; Machek 1957: 319-320). Корен *ny- поједини истраживачи виде и у називу словенског старопољског божанства „Nуа“, које се помиње у Длугошевој Хрониии из XV века (ЭССЯ 1997: 51; Дукова 2015: 65). Набрајајући словенска божанства, Јан Длугош наводи да Нија код Словена одговара Плутону, „богу подземља (пакла) и душа мртвих“ (Dlugossi 1964: 107).

У народној култури Словена неутрално значење лексема с кореном *navb- (мриивак, йокојник) с временом је добило значење „нечисти покојници, демони“. У западној Бугарској, затим у Србији (од Мораве на западу до границе с Бугарском на истоку), па на југу до етничке словенско-грчке границе веровало се да се душе умрле некрштене деце претварају у птице и могу да повреде, пре свега, породиље и новорођенчад. У источној Србији су их називали навће, навије, навивје, навијенће, навјетй док су јужно од Врања били познати као наве, навои, затим у Бугарској као навяк, навляк, а у западној Македонији као нави, најващи, навои (Раденкович 2014: 206; Раденкович 2016: 142). Према народним веровањима на поменутим територијама, некрштена мала деца или новорођенчад која су умрла и која су лишена мајчиног млека ноћу лете у форми птица и траже породиљу, којој потом са млеком исисају и крв и на тај начин је усмрте. У Словенији се, исто тако, веровало да се душе некрштене деце претварају у велике црне птице navje, mavje, movje, које летећи траже човека који би их крстио. Уколико би неко чуо њихов плач, требало је да руком у ваздуху начини крст и надене им неко библијско име (Адам, Ева, Ана, и сл.) или да руком узме мало воде из потока и прсне је у правцу гласа, говорећи: „Krstim te navje v imenu Boga očeta, sina in svetoga duha“" (Раденкович 2014: 210). С друге стране, у Украјини душе некрштене деце мавки или нявки имају сличности са вилама у српским народним веровањима, а код Хуцула нявка спреда изгледа као девојка, док јој се на леђима провиди утроба. Душе некрштене деце у виду девојака се јављају и у народним веровањима на југу Србије, у Македонији и Бугарској (Раденкович 2014: 206, 209). 
У Индексу забрањених књиїа руског митрополита Зосиме (XV век), у оквиру осуде богумилског учења попа Јеремије, такође се помињу нави: „Былъ въ навђхъ на верзіуловъ колу“ (Драгојловић 1974: 36). Различита тумачења имена Верзил или Верзиул утицала су и на тумачења семантике лексеме нав. С једне стране, сматра се да се иза имена Верзила/ Верзиула може крити лик Велзевува, односно Белзебуба, семитског божанства. По свој прилици су павликијани (манихејци), код којих је Белзебуб изједначен са ђаволом, пренели на Балкан знање о њему у периоду од VII до Х века (Драгојловић 1974: 36). У том случају би „быль въ навЪхъ“ значило да је Јеремија „био међу мртвима, на оном свету, у колу Белзебуба“"2 (Топорков 2016: 276). С друге стране, Јагић је у Верзиловом колу видео магијски круг Вергилија, великог мага средњовековних предања која су стигла и до Јужних Словена, па је поменути израз тумачио као „стећи знање о магији, црнокњижју“. Нави би у том случају означавали демоне (Топорков 2016: 276).

\section{3. Табу називи}

Код свих словенских народа се избегавало изговарање личног имена како умирућег тако и покојника. У Русији је посебно опасно било помињати име „нечистог“ покојника (рус. заложный йокойник) (Зеленин 1929: 147). У западној Србији, у ужичком, пожешком и косјерићком крају, самртнику се нису обраћали по имену, због тога што се веровало да би му се душа „предвојила“ или „пресекла“, па не би могао да умре: „Душа би му полазила и враћала се, па би се умирање продужило и отежало“ (Благојевић 1984: 280). У источном делу Поморавља се говорило и да би му се душа „прецепила“(Антонијевић 1971: 153). Из истог разлога је било забрањено гласно плакање и нарицање за самртником у часу умирања. У Чешкој је, такође, било забрањено да се гласно говори (пошто би нарушили умирућем мир), као и да се самртник ословљава по имену, због тога што се веровало да ће му се тело укочити: „Přitom nesměli mluvit nahlas, aby nerušili jeho klid, a nesměli ho oslovit jménem, jinak by mu ztuhly údy“ (Brouček, Jeřábek 2007: 619).

Како је раније наведено, помињање човека који је умро по имену се избегавало у задушним ритуалима и у периоду жалости из страха да не буде дозван. Један од најчешћих „сигурних“ општих назива, који се јавља код свих словенских народа, јесте йокојник. Семантика поменуте лексеме је прозрачна - у питању је онај који се налази у стању (c) покоја (неактивности и у материјалном и у духовном смислу), одмора, мира, тишине, одсуства бриге (Даль 1980: 242). Иначе, йокој означава и прекидање неке активности или стања, тако да је у руском језику овом

2 Није без значаја и чињеница да су Јеремију после смрти проболи коцем, као што се чинило у случају нечистих и повампирених покојника (Топорков 2016: 276). 
речју означавано и само умирање, крај живота (Срезневский 1893: 1110; СРЯ 1990: 164).

Код Срба је преминули, између осталог, именован као „покојник, или јадник, или веселник“ (Чајкановић 1994: 174). Примери јаgник и веселник одсликавају противречне народне представе према смрти и покојнику. Иако Чајкановић не прецизира, јаgник се у народном именовању неретко односи на покојника који, према субјективном мишљењу говорника, није имао среће током живота или је дуго боловао и мучећи се умро. Такође, имплицитно се не изражава само жаљење за покојником, већ се показује и негативан однос према смрти (наспрам позитивног вредновања живота). Исти начин именовања покојника је посведочен у Горњем Полимљу: несрећник, јаgо (Барјактаровић 1985: 170).

Назив веселник за покојника, као и концепт весеља, на први поглед је неприродан и супротан сфери смрти. У оквиру одреднице веселик Вук наводи да се „веселиче један“ најчешће говорило уместо „јадниче“ када би некога грдили: „Кад кога жалећи карају, мјесто 'јадниче', 'несретниче'! Као што мати дјетету рече, на пример: 'Шта си то учинио, весео мајци био', мјесто: 'Жалосна ти мајка!'“(Караџић 1986: 105). У Речнику срйско-

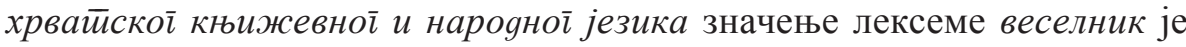
такође једнако значењу лексеме јаgник - „онај који изазива сажаљење, саучешће, несрећник, јадник“ (РСАНУ 1962: 542). Међутим, у народној култури Словена весеље (и лексика која га прати) у погребним обредима има магијску заштитну функцију. На пример, уколико би у породици умирала деца, код Срба у Лесковачкој Морави је био обичај да мајка почне да пева песму приликом изношења последњег преминулог детета из куће. Притом, на одећи или у коси би носила босиљак, који се сматрао симболом весеља и радости. Уколико је у некој породици било више смртних случајева у кратком временском периоду, у Такову је једна особа из породице имала обавезу да најгласније што може запева било коју песму у току служења панахије, пошто се сматрало да се тиме прекида даље умирање (Филиповић 1972: 175). Таква песма, којом се магијски могла зауставити смрт, називана је понегде веселица (Толстой, Толстая 1993: 177). У Далмацији се веровало да деца која умру постају анђели и заступници породице на небесима, па су суседи и родбина долазили на „радовање“ код породице којој је умрло мало дете (Schneeweis 2005: 137). С друге стране, код Источних Словена су познате игре поред покојника приликом његовог „чувања“ у току ноћи. Дакле, назив веселник за покојника има првенствено заштитну магијску функцију. Уколико се покојник именује на тај начин, симболички му се поручује да треба да буде весео $^{3}$, односно да прихвати свој нови положај, а не да тежи да остане на овом свету. Такође, тиме се упућује и на представу о смрти као новом почетку, односно стадијуму у ком човекова душа одлази на онај свет

3 Детаљније о семантици словенског *vesel- в. Толстая 2010. 
и ужива у красотама раја. У складу са тим, у Височкој нахији се на ручку после погреба обавезно наздрављало покојнику уз речи: „Вјечна му радост“" (Филиповић 1949: 180).

Назив gобросрећник за покојника се може тумачити у истом кључу, као и претходно разматрани назив - као еуфемистички назив и као назив са заштитном функцијом (Зеленин 1929: 155; Вакарелски 1990: 53).

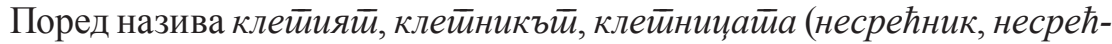
нииа), яgен, яяник (јаgан, јаяник), сиромах, сиройа, сиромащка, у Бугарској се срећу и називи факирин и факирка за покојника, односно покојницу (Вакарелски 1990: 53). У примеру факирин се може препознати утицај муслиманске културе, с обзиром на то да факир у турском језику (тур. fakir) значи сиромах (Śkaljić 1979: 276).

Уз назив йокойник (иокојник), у руском језику је у прошлости широко био заступљен облик уйокойник (од „упокоиться“) (уйокојийи се) (Зеленин 1929: 152). Како би избегли лично именовање преминулог, у вологодском крају су најчешће говорили „покойник в доме“ или „покойна головушка“ (Зеленин 1929: 146). Владимир Даљ бележи и архаични облик исте основе - йокоенка, као и облик посведочен у тверској, орловској и калушкој области - жмурик (Даль 1978: 546). Други пример привлачи пажњу, с обзиром на то да је мотивисан изгледом мртвог човека коме су очи затворене. Тиме је живот изједначен са гледањем и видом, док је за смрт везан губитак вида и мрак.

У народном говору се јавља и назив сойный (онај који сйава): „Конечно, сопный, мертвый-то“ (Наравно, сойный је мрйваи) (СРЯ 2002: 159; СРНГ 2005: 340). Слично томе, сойня означава дрво које је предвиђено за сечу (СРНГ 2005: 340). С друге стране, назив усоищий књижевног је порекла и настао је осамостаљивањем од израза „усопший (уснувший) вечним сном“ (онај који је засйао вечним сном) (Зеленин 1929: 152).

У белоруском, украјинском, пољском и чешком језику се јављају и називи покојника с кореном bog-: небоїо (минска област); небоі̄o, небiщик (укр.); небощик, небіщик, нябощик (белорус.) (Седакова 2004: 224); nieboszczyk (пољ.) (Adamowski, Doda 1998: 266); nebožtik, nebožčik, nebožec, nebohý, nebožák (чеш.) (Machek 1957: 321; Седакова 2004: 43). Према народној етимологији, називи небощик и nieboszczyk се доводе у везу са небом и тумаче као небожийель, односно „становник неба, онај који је на небу“. Ипак, њихово значење је пре везано за „бог, богат“ (Зеленин 1929: 146), што одговара и српскохрватском „убог“.

У народној култури словенских народа убоіи (просјак) у погребним обредима често преузима улогу покојника. Чајкановић је сматрао да је до преноса значења од убоі (просјак) до убоі (покојник) дошло управо због обичаја дељења и даровања хране просјацима на гробљу, што се на симболичком плану сматра заједничким обедом са прецима (Чајкановић 1994б: 101). С друге стране, разматрајући наведене називе, Олга Седакова наводи мишљење Иванова и Топорова да у овим примерима сло- 
венско bog- у реконструисаном значењу може да се изједначи са gољом (уделом среће који човек добије рођењем) (Седакова 2004: 266, 268). Уз одричне префиксе (не-, $y$-), поменуте лексеме добијају значење смрти као одсуства доље.

У Босни и Херцеговини, у западној Србији (Горње Драгачево, ужички, пожешки, косјерићки крај), у таковској области, затим код муслима-

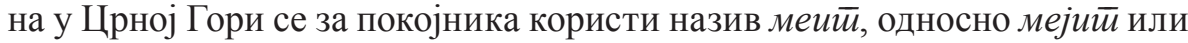
мејш̄ (Bajić 1978: 55-58; Николић 1996: 95; Благојевић 1984: 282; Дучић

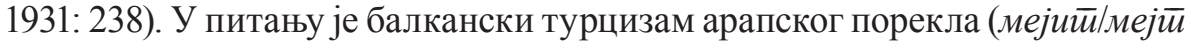
$<$ тур. meyyit < ap. mayyit, mayt), са значењем мрйав, ирреминуо, умрли, мришваи (Šehović, Haverić 2017: 203; Skok 1972/II: 400), који се већином јавља код муслиманског, али и хришћанског становништва: „Каравласи кажу нека Бог казни да руке трну онога ко ради, а мејт (мртвац) је још у кући“ (Бајић 1979: 328); „у свим селима у Семберији покојника зову 'мејт'“ (Бајић 1979: 329); „био је обичај да онај који је купао 'мејита' не сеје ништа нити је од њега узимао на зајам семе да сеје, док он не 'оброћи'4 руке“ (Филиповић 1972: 169). Вук је забележио облик меий са значењем мрйваи, уз који је навео и стихове песме „Жеља и по смрти“: „Не копај ме, нено, / Гдје се меит копа“ (Караџић 1986: 494). У Речнику САНУ и у Речнику ЈАЗУ наводи се да је лексема меити, односно мејий развила и секундарно значење йоіреб, сахрана, сйровоg (РСAHУ 1984: 329; RJAZU 1904-1910: 585).

Као регионални назив треба навести и латинизам каgавер у хрватском приморју или, на острву Брачу, каgивер (од лат. cadaver - мрииво йело, лещи, мрииваи) (РСАНУ 1975: 47; Јовановић 1958: 134).

Међу словенским народима се избегавало и директно помињање смрти како би се избегао контакт са њом. У Србији се, стога, говорило (и говори) растиавио се с gущом, йреминуо, найусииио нас, йреселио се

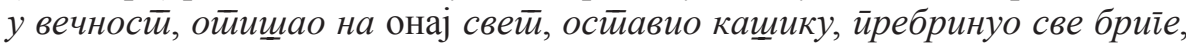
док се за човека који је умро у дубокој старости или тешкој болести говорило ояморио се, а за дете - йионуло (Благојевић 1984: 281-282). У Војводини се о покојнику обично говорило расииавио се с gущиом, богуу gущиу

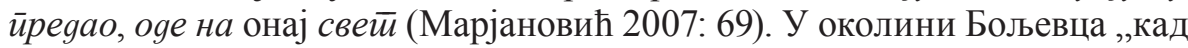
ко умре, народ никад неће казати да је умро, него да је нестао“ (Грбић 1909: 242), као и у хомољском крају (Милосављевић 1914: 240). Већина наведених примера указује на представу о смрти као растављању тела с душом, при чему душа наставља своје постојање на другом свету, док примери остиавио кащику и ирребринуо све бриіе упућују на представу о смрти као престанку овоземаљских активности - по наступању смрти се губе телесне потребе за храном, као и животне бриге.

${ }^{4}$ Веровало се да после сахране људи треба да обоје прсте или шаке у црвену боју која се добијала од биљке броћа и тако се „очисте“ од контакта са покојником, односно смрћу (Раденковић 1996: 294-295). 
Код других словенских народа се јављају готово иста именовања смрти и покојника. У Бугарској се говорило да покојник йочива, да oge или оgе у земљу: „почина“, „отиде си“, „сбогува се със земята“ (Вакарелски 1990: 25). Народна представа о покојнику који путује на онај свет је реализована и у начину на који се покојник именује, па се он именује и као $\bar{u} y \bar{u} н и к-\bar{u} а \bar{u} н и к, \bar{u} ъ \bar{u} н и к$ (Седакова 2004: 226, 229). С друге стране, у словеначком језику се умирање може именовати као одлазак на небеско весеље или гозбу: „Šel je v nebeško veselje“ ( умро је) (Толстой, Толстая 1993: 177), па је покојник стиановник раја — rajnik, rajnica, rajni.

С обзиром на то да покојник више не припада овом свету, он постаје

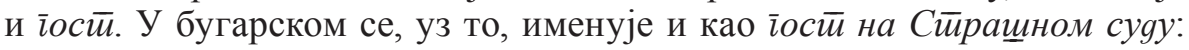
„гостенин, гостенин на Страшния суд“ (Седакова 2004: 216). У руским, белоруским и литванским тужбалицама се, такође, запажају обраћања покојнику као госту и путнику. У њима се покојник позива да прими почаст коју му породица одаје пре него што оде на „далеки пут“ и придружи се групи умрлих предака-покровитеља: „Дорогой гость, почтенный мой, / Погости-ко, мой батюшка, / Во своем благодатном дому““ (Дра-

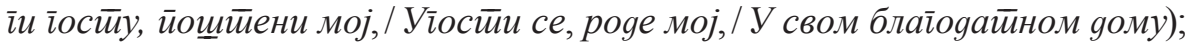
„Пакідаеш нас, татулечка, / Ты ж наш госцічак, наш міленькі: нямнога

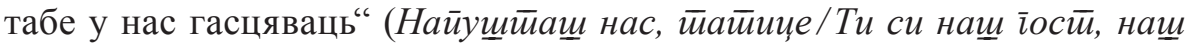

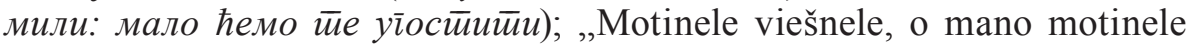
keliauninkele“" (Мамице іомћћо, о моја мајко иууйнице) (Невская 1998: 53).

\section{4. Називи йокојника у зависносӣи оg начина на који је умро}

Претпоставља се да се још у периоду када су словенска племена живела у заједништву правила разлика између лексема с кореном *mrt-/ *mr- / *mer- / *mor-, с једне стране, и лексема с кореном * $*_{y b-} / *_{g z} b-/$ *gub-, с друге стране (Жуйкова 1998: 78). Прасловенско *sb-mbrtb, према

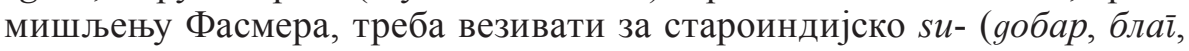
uравилан) и mrtis (cмp $\bar{u})$. Тиме би првобитно значење лексеме *sъmbrtb било „блага/добра смрт“, односно „природна смрт“, „своја смрт“ (Фасмер 1971: 685; Жуйкова 1998: 77; Machek 1957: 311). Супротно томе, лексеме с кореном *gyb- / *gъb- / *gub- упућују на нейрироgну, нейравилну, односно насилну или прерану смрт. Потврду овој хипотези дају глаголи у сло-

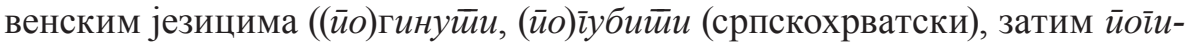

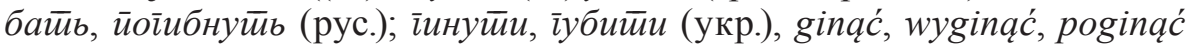
(пољ.), итд.), који представљају рефлексе поменутог корена, а чије је првобитно значење било „постајати крив“, „кривити се“ или „правити кривим“ (Жуйкова 1998: 68). У народној култури свих словенских народа обележје йраво има увек позитивни предзнак - то је уједно и зяраво, gобро, везано за живот, док је криво перципирано као болесно, лоще и везивано је за онај свет. Пренос значења глагола іубийи од „постајати 
крив“ до „лишавати (неког) живота“, „умирати“ у основи има идеју о физичком страдању, које подразумева деформацију тела, па онда и значење „неприродне“, случајне, неочекиване смрти (Жуйкова 1998: 70).

Поред заједничког назива йоїинули и самоубица, у словенским језицима се срећу и специфични називи који детаљније описују начин на који је покојник завршио свој живот, што је утицало и на народну представу о његовом месту на оном свету. Код свих словенских народа се веровало да самоубице припадају „нечистим“ покојницима, који не могу да оду на онај свет и не могу да нађу мир, па су, због тога, веома опасни по живе - могу их узнемиравати, предводити олују, градоносне облаке или изазвати сушу. Сматрало се и да је само место несреће „нечисто“ и да га душа самоубице не напушта. Због тога такви покојници нису сахрањивани на гробљу, већ изван њега, обично на граници атара. Код Срба у Барањи се веровало да они остају на овом свету и лутају по грању: „Није лако доћ’ пред Божји суд. Душа иде по уском путу, по уској дасци, једва може проћ', па кроз грање, па онда опет по уској дасци. Презноји се док тамо не стигне. Душе, које небо не прими, лутају по грању“ (Дворнић 2019: 134).

На Косову је забележен назив за жену која се сама удавила - самоуgављеница (Дебељковић 1907: 323), док су у југоисточној Србији у Бучићу називом самоgавник именовали „жену која се удавила у бунар и она се сахрањује изван гробља“" (Борели 1958). С друге стране, човек који се обесио је у народу био познат као обещеник, објещеник или обещењ $а к$, објещењак. Према народним веровањима, обешењаци могу да предводе градоносне облаке и олују. Уколико би приметили градоносне облаке, у Шумадији су људи позивали последњег обешењака или удављеника из села да одведе „бела говеда“ (облаке) на другу страну. У Македонији се веровало да душа удављеника предводи градоносни облак, који су звали „облак неверник“ (Вражиновски 2001/2001: 41). У кумановском крају су на Бадњи дан, ради заштите у току године, позивали „облака неверника“ на „вечеру“, говорећи: „Облаче неверниче, дојди с'га да вечерамо и да се видимо, па цело лето да не се видимо“ (Вражиновски 2001/2001: 43-44). У Рипњу се веровало да душе људи који су одузели себи живот могу направити и другу штету: „Самоубице на оном свету стално лете и трче. Бог их ухвати, метне их у буре, па их затвори. Кад их пусти, они јуре као ветар, лудују. То су вијори. Запале сено, преврну оџак. Вијор кад бесни, бесне обешењаци“ (Петровић 1939: 37).

У руском језику се, такође, јављају називи уgавленник и уйойленник за покојника који се удавио. Пажњу привлачи податак да се у Полесју у другој половини $\mathrm{XX}$ века изменио однос према утопљеницима. Док су раније сврставани у исту категорију „нечистих“ покојника са обешењацима, крајем XX века се у појединим деловима поменуте области јавља и пракса сахрањивања и давања помена овим покојницима (НДП 2012: 402). По свој прилици је на промену односа утицала немогућност тачног 
утврђивања начина на који се неко удавио - самовољно или несрећним случајем. С друге стране, у Пољској се јављају народна веровања о демону воде (topielnik), који настаје од утопљеника. У западном Полесју се такав демон назива йойойлэник, йойлэник, ууйойленик, али се у народним веровањима може изједначити и са самим утопљеником који вуче људе на дно реке како би их удавио (НДП 2012: 403).

Код Источних Словена је покојник који се обесио - висельник (висельница), вищальник - такође сматран врло опасним, посебно уколико би био сахрањен у гробљу (Даль 1978: 207; НДП 2012: 402). Веровало се да, у том случају, може доћи до временских непогода и велике суше.

\section{5. Закључна размайрања}

Називи покојника код словенских народа се могу поделити у више група и на више начина. Прво, могу се издвојити две велике групе, чији је главни фактор формирања начин на који је покојник умро. Прву групу чине називи који упућују на то да је покојник умро „природном“ или „својом“ смрћу (називи с кореном *mrt- / *mr- / *mer- / *mor-), док су у другој групи називи који се користе за покојнике који су умрли прераном, насилном, „неприродном“ смрћу (називи с кореном *gyb- / *gъb- / * $g u b-)$. У другу групу се сврставају и називи којима се детаљније говори о начину умирања (самоуgављеница, обещенък, удављеник, итд.). Начин на који је човек умро је утицао и на народну представу о његовом месту на оном свету, па су покојници из прве групе сматрани прецима (Деgь код Источних Словена), док су покојници из друге групе сматрани „нечистим“ покојницима и неретко су изједначавани са демонским бићима.

У семантичком развоју назива с кореном *navb- издвајају се два правца. Код јужнословенских народа и Украјинаца се почетно значење мрииваи с временом изменило у gуще йокојника, па затим у некрщииени йокојници, демонско биће које найаgа йородиље (Бугарска, Македонија, Србија), gуще некрийене яеще (Словенија), некршитена девојка која се йосле смрими йретивара у русалку (Украјина). На чешкој и словачкој територији се од значења мрйваи, преко значења $\overline{p o б, ~ д о ш л о ~ д о ~ з н а ч е њ а ~}$ заїробни свети, аg, йакао.

Поред тога што сви имају магијску заштитну функцију, једну групу табу назива чине они који се заснивају на еуфемистичком именовању покојника (веселник, gобросрећник). У основи ове групе се налази народна представа о оном свету као месту вечне радости. За другу групу је заједничко позитивно вредновање живота и негативно вредновање смрти (јаgник, јаgо, яgен, клетиия $\bar{u}$, итд.). Трећа група табу назива је формирана око народне представе о смрти као нестанку свих земаљских благодати, односно нестанку „доље“ (сиромах, сиройа, несрећник, убой, небог̆о, небощик, небіщик, нябощик, итд.). Назив жмурик је мотивисан 
изгледом преминулог (покојнику су се обавезно затварале очи), док се називи йокојник, йокоенка, усоищuй заснивају на представи о његовом стању (онај који је заспао вечним сном и који се налази у стању (с)покоја).

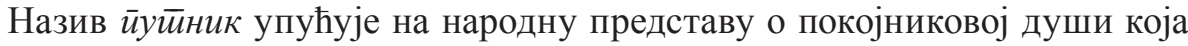
се, пошто напусти тело, задржава неко време на овом свету да би га потом заувек напустила. Међу табу називима треба издвојити и оне који су настали услед контакта словенских народа са другим културама и наро-

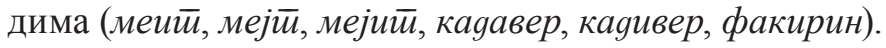

За све називе покојника међу словенским народима је карактеристично да фреквенција њихове употребе зависи и од контекста. Уколико би говорници били у непосредној близини мртваца, најчешће би бирали „неутралне“ називе (попут йокојник или мејші), док би се неки други називи чешће користили у приликама када је постигнута просторна и временска дистанца (од покојника и смрти уопште).

\section{ЛИТЕРАТУРА}

Антонијевић Драгослав. „Алексиначко Поморавље“. СЕЗб. LXXX. Београд, 1971.

Бајић Светлана. „Погребни обичаји и надгробни споменици сеоског становништва у Сем-

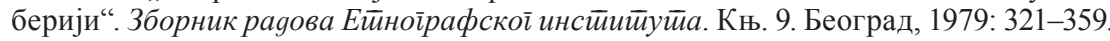

Барјактаровић Мирко. „О смрти и сахрани у Горњем Полимљу“. Гласник Ейноїрафской музеја у Беоїраяу. 49 (1985): 163-172.

БЕР 1995: Бълїарски ейимолоїичен речник. T. IV. София, 1995.

Благојевић Наталија. „Обичаји у вези са рођењем, женидбом и смрћу у титовоужичком, пожешком и косјерићком крају“. Гласник Еӣнойрафской музеја у Беоїраgу. 48 (1984): 209-310.

Борели Рада. Рукойисна ірађа: Бучић. Теренска исииражсиваға. 11. VII 1958, 1958.

Братић Тома. „Свадбени и погребни обичаји на селу у Горњој Херцеговини“. Гласник Земаљскои музеја. XV/1 (1903): 385-401.

Вакарелски Христо. Бълїарски йор̄ребални обичаи. Сравнииеелно изучаване. София, 1990.

Веселовский А. Н. „Молитва св. Сисиния и Верзилово коло“. Журнал Министерства наровнойо просвещения. 5 (1895): 226-234.

Власова Марина. Русские суеверия. СПб., 2018.

Вражиновски Танас. „Градоносните облаци во македонската народна традиција“. Ейнокулитуролощки зборник. VII (2001/2002): 41-47.

Гальковский Николай. Борьба христианства с остатками язычества. Т. 1. Харков, 1916. Грбић Саватије. „Српски народни обичаји из среза Бољевачког“. СЕЗб. 14. Београд, 1909. Даль Владимир. Толковый словарь живаго великорускаго языка. Репринт. Т. 1. М., 1978. Даль Владимир. Толковый словарь живаго великорускаго языка. Репринт. Т. 2. М., 1979. Даль Владимир. Толковый словарь живаго великорускаго языка. Репринт. Т. 3. М., 1980. Дворнић Милан. Нарояни обичаји Срба у Барањи. Бели Манастир, 2019.

Дебељковић Дена. „Обичаји српскоп народа на Косову пољу“. CEЗб. VII. Београд, 1907. Драгојловић Драгољуб. „Врзино коло и јеретичка традиција о Верзевулу код Јужних Словена“. Нарояно сииваралащӣво/Folklor. XIII/49-52 (1974): 35-40.

Дукова Уте. Наименования яемонов в болгарском языке. М., 2015.

Дучић Стеван. „Живот и обичаји племена Куча“. СЕЗБ. LXVIII. Београд, 1931.

Ердељановић Јован. „Етнолошка грађа о Шумадинцима“. CE3б. LXIV. Београд, 1951.

Журавлев Анатолий. Ф. Язык и миф. Лингвистический комментарий к труgу А. Н. Афанасьева „Поэтические воззрения славян на прироgу”. М., 2005. 
Жуйкова Маргарита. „Номинация смерти и архаическое мышление“. Etnolingwistyka. 9/10 (1998): 67-80.

Захариев Йордан. „Кюстендилско крайще“. Сборникъ за нарояни умойворения и нароgойисъ. София, 1918.

Зеленин Дмитрий К. „Табу слов у народов восточной Европы и северной Азии“. Сборник Музея антропологии и этнографии. 9. Л., 1929.

Иванов Вячеслав В., Топоров Владимир Н. (ред.-сост.) Мифы нароgов мира. Энциклопеgия. Т. 2. М., 1982.

Иванов Владимир В. „Лингвистические материалы к реконструкции погребальных текстов в балтийской традиции“. Балто-славянские исслеgования 1985. М., 1987: $3-9$.

Јовановић Милка. „Посмртни обичаји и гробље у Сутивану“. Гласник Еӣнойрафскоі инстиийуйа САНУ. VII (1958): 133-140.

Караџић Вук. Срйски рјечник (1852). Сабрана дела Вука Карацића. Књ. 11. Београд, 1986. Кнежевић Сребрица, Јовановић Милка. „Јарменовци“. СЕЗб. LXXIII. Београд, 1958.

Марјановић Весна. „Комуникација с традицијом на примеру погребног ритуала

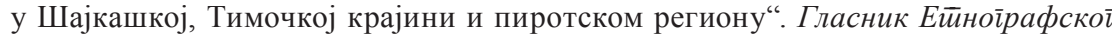
музеја у Беоїpagy. 71 (2007): 63-78.

Милосављевић Сава. „Српски народни обичаји из среза хомољског“. СЕЗб. ХІХ. Београд, 1914.

НДП 2012: Народная gемонология Полесья. Т. 2. Виноградова Л. Е., Левкиевская Е. Е. Демонологизачия умерших люgей. М., 2012.

Невская Лидия. „Семантическая структура балто-славянского погребального причитания““. Etnolingwistyka. Problemy języka i kultury. Bartminski J. (red.). 9/10 (1998): $51-66$.

Николић Владимир. „Из Лужнице и Нишаве“. СЕЗб. XVI. Београд, 1910.

Николић Десанка. Горње Драйачево (Ейнолощко ироучавање кулйурних йромена). Београд. 1996.

ПВЛ 1950: Повесть временных лет (по Лаврентьевской летописи). 1377 г. М., Л.

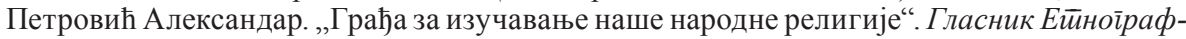
скоі музеја у Беоїpagy. XIV (1939): 31-42.

Петровић Атанасије. „Народни живот и обичаји у Скопској Црној Гори“. CE3б. VII. Београд, 1907.

Раденковић Љубинко. Симболика свет̄а у нарояној майији Јужних Словена. Београд, 1996.

Раденкович Любинко. „Названия демонов, ведущие происхождение от детей, умерших до крещения у славян“. Balcanica. XXIV (2014): 203-221.

Раденкович Любинко. „Ходячий покойник в духовной культуре славян“, (ред) А. А. Алексеев, Н. П. Антропов, и т. д. Slavische Geisteskultur: Ethnolinguistische und philologische Forschungen. T. 1. Славянская gуховная культура: этнолингвистические и филологические исслеgования, ч. 1, Frankfurt am Main, 2016: 141-156.

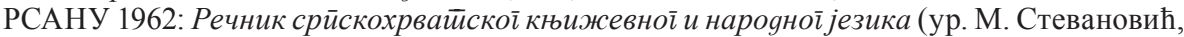
М. Павловић и др.). Књ. ІІ (Богољуб - Вражогрнци). Београд, 1962.

РСАНУ 1975: Речник срйскохрвайскої књижевної и нарояної језика (ур. М. Стевановић, М. Пешикан и др.). Књ. ІХ (јургет-колитва). Београд, 1975.

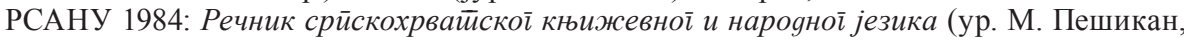
И. Грицкат-Радуловић и др.). Књ. ХІІ (маквеи-мозурица). Београд, 1984.

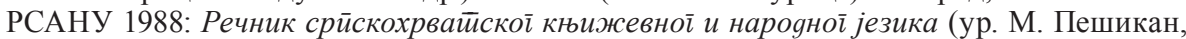
И. Грицкат-Радуловић и др.). Књ. ХІІІ (моире-наклапуша). Београд, 1988.

Седакова Ольга. Поэтика обряgа. М., 2004.

СЕЗб - Срйски ейнойрафски зборник. Београд, 1894- .

Срезневский Измаил И. Матеріалы gля словаря яревне-русскаго языка. Т. 1. 1893.

Срезневский Измаил И. Матеріалы gля словаря яревне-русскаго языка. Т. 2.1902.

СРНГ 2005: Словарь русских нарояных говоров. Вып 39. СПб., 2005. 
СРЯ 1983: Словарь русского языка XI-XVII вв. (ред. Ф. П. Филин). Вып 10. М., 1983. СРЯ 1990: Словарь русского языка XI-XVII вв. (ред. Г. А. Богатова). Вып 16. М., 1990. СРЯ 2002: Словарь русского языка XI-XVII вв. (ред. Г. А. Богатова). Вып 26. М., 2002. Станић Милија. Ускочки речник. 1. Београд. 1990.

Толстая Светлана М. „К семантической реконструкции слав. *vesel- и *rad- “. Praslovanska dialektizacija v luči etimoloških raziskav. Ob stoti obletnici rojstva akademika Franceta Bezlaja. ur. M. Furlan, A. Šivic-Dular. Ljubljana, 2010: 257-264.

Толстой Никита И., Толстая Светлана М. „Слово о обрядовом тексте (культурная семантика слав. *vesel-)“. Толстой Н. И. (ред.) Славянское языкознание. Межяународный сьезя славистов. Братислава, 1993. Доклая россиской делегащии. М., 1993: 162-186.

Топорков Андрей Л. „Веселовский как исследователь 'Сисиниевой легенды'“. Говенько Т. В. (ред.) Наслеgие Алексанgра Веселовского в мировом контексте: Исслеgования и материальл. М.; СПб., 2016: 263-282.

Фасмер Макс. Этимологический словарь русского языка. Т. 3. М., 1971.

Филиповић Миленко. „Живот и обичаји народни у Височкој нахији“. CE3б. LXI. Београд, 1949.

Филиповић Миленко. „Таковци“. СЕЗб. LXXXIV. Београд, 1972.

Чајкановић Веселин. Сӣуgије из срӣске релиїије и фолклора. Београд, 1994.

Чајкановић Веселин. Сйара срйска релиїија и мийолойија. Београд, 19946.

ЭССЯ 1997: Этимологический словарь славянских языков: Праславянский лексический фоня (ред. О. Н. Трубачев). Вып 24. М., 1997.

Adamowski Jan, Doda Jadwiga, Mickiewicz Halina. „Śmierć i pogrzeb w relacjach Polaków mieszkających na Białorusi“. Etnolingwistika. 9/10 (1998): 253-318.

Bajić Svetlana. „Arhaični elementi u pogrebnim običajima muslimana u Janji“. Нароgно стиваралашӣво. Folklor. XVII/65 (1978).

Brouček Stanislav, Jeřábek Richard (red.). Lidová kultura. Národopisná encyklopedie Čech, Moravy a slezska. Sv. 2. Praha, 2007.

Dlugossi Joannis. Annales seu Cronicae incliti regni Polonia / opera venerabilis domini Joannis Dlugossii. Lib. 1. Varsaviae, 1964.

Gliha Komac Nataša. „Ljudska religioznost v kanalski dolini. O umiti in v prt zaviti lobanji“. Studia mythologica Slavica. Supplementa 9. Ljubljana, 2014.

Machek Václav. Etymologický slovnik jazyka českého a slovenského. Praha, 1957.

RJAZU 1904-1910: Rječnik hrvatskoga ili srpskoga jezika. VI (lekenički-moračice), Zagreb, 1904-1910.

Schneeweis Edmund. Vjerovanja i običaji Srba i Hrvata. Zagreb, 2005.

Skok Petar. Etimologijski rječnik hrvatskoga ili srpskoga jezika. Knj. 2 (K-poni). Zagreb, 1972.

Šehović Amela, Haverić Đenita. Leksika orijentalnog porijekla u frazemama bosanskog jezika. Sarajevo, 2017.

Škaljić Abdulah. Turcizmi u srpskohrvatskom jeziku. IV izdanje. Sarajevo, 1979.

\section{LITERATURE}

Adamowski Jan, Doda Jadwiga, Mickiewicz Halina. „Śmierć i pogrzeb w relacjach Polaków mieszkających na Białorusi“. Etnolingwistika. 9/10 (1998): 253-318.

Antonijević Dragoslav. „Aleksinačko Pomoravlje“. SEZb. LXXX. Beograd, 1971.

Bajić Svetlana. „Arhaični elementi u pogrebnim običajima muslimana u Janji“. Нароgно стиваралащӣво. Folklor. XVII/65 (1978).

Bajić Svetlana. „Pogrebni običaji i nadgrobni spomenici seoskog stanovništva u Semberiji“. Zbornik radova Etnografskog instituta. Knj. 9. Beograd, 1979: 321-359.

Barjaktarović Mirko. „O smrti i sahrani u Gornjem Polimlju“. Glasnik Etnografskog muzeja u Beogradu. 49 (1985): 163-172.

BER 1995: B'lgarski etimologichen rechnik. T. IV. Sofiya, 1995. 
Blagojević Natalija. „Običaji u vezi sa rodjenjem, ženidbom i smrću u titovoužičkom, požeškom i kosjerićkom kraju“. Glasnik Etnografskog muzeja u Beogradu. 48 (1984): 209-310.

Boreli Rada. Rukopisna gradja: Bučić. Terenska istrazhivanja. 11. VII 1958, 1958.

Bratić Toma. „Svadbeni i pogrebni običaji na selu u Gornjoj Hercegovini“. Glasnik Zemaljskog muzeja. XV/1 (1903): 385-401.

Brouček Stanislav, Jeřábek Richard (red.). Lidová kultura. Národopisná encyklopedie Čech, Moravy a slezska. Sv. 2. Praha, 2007.

Čajkanović Veselin. Studije iz srpske religije i folklora. Beograd, 1994.

Čajkanović Veselin. Stara srpska religija i mitologija. Beograd, 1994b.

Dal' Vladimir. Tolkovyj slovar' zhivago velikoruskago yazyka. T. 1. M., 1978.

Dal' Vladimir. Tolkovyj slovar' zhivago velikoruskago yazyka. T. 2. M., 1979.

Dal' Vladimir. Tolkovyj slovar' zhivago velikoruskago yazyka. T. 3. M., 1980.

Dvornić Milan. Narodni obichaji Srba u Baranji. Beli Manastir, 2019.

Debeljković Dena. „Običaji srpskog naroda na Kosovu polju“. SEZb. VII. Beograd, 1907.

Dlugossi Joannis. Annales seu Cronicae incliti regni Polonia / opera venerabilis domini Joannis Dlugossii. Lib. 1. Varsaviae, 1964.

Dragojlović Dragoljub. „Vrzino kolo i jeretička tradicija o Verzevulu kod Južnih Slovena“. Narodno stvaralaštvo/Folklor. XIII/49-52 (1974): 35-40.

Dukova Ute. Naimenovaniya demonov v bolgarskom yazyke. M., 2015.

Duchić Stevan. „Život i običaji plemena Kuča“. SEZb. LXVIII. Beograd, 1931.

Erdeljanović Jovan. „Etnološka gradja o Šumadincima“. SEZb. LXIV. Beograd, 1951.

ESSYA 1997: Etimologicheskij slovar' slavyanskih yazykov: Praslavyanskij leksicheskij fond (red. O. N. Trubachev). Vyp 24. M., 1997.

Fasmer Maks. Etimologicheskij slovar' russkogo yazyka. T. 3. M., 1971.

Filipović Milenko. „Život i običaji narodni u Visočkoj nahiji“. SEZb. LXI. Beograd, 1949.

Filipović Milenko. „Takovci“. SEZb. LXXXIV. Beograd, 1972.

Gal'kovskij Nikolaj. Bor'ba hristianstva s ostatkami yazychestva. T. 1. Harkov, 1916.

Gliha Komac Nataša. „Ljudska religioznost v kanalski dolini. O umiti in v prt zaviti lobanji“. Studia mythologica Slavica. Supplementa 9. Ljubljana, 2014.

Grbić Savatije. „Srpski narodni obichaji iz sreza Boljevačkog“. SEZb. 14. Beograd, 1909.

Ivanov Vyacheslav V., Toporov Vladimir N. (red.-sost.) Mify narodov mira. Enciklopediya. T. 2. M., 1982.

Ivanov Vladimir V. „Lingvisticheskie materialy k rekonstrukcii pogrebal'nyh tekstov v baltijskoj tradicii“. Balto-slavyanskie issledovaniya. 1985. M., 1987: 3-9.

Jovanović Milka. „Posmrtni običaji i groblje u Sutivanu“. Glasnik Etnografskog instituta SANU. VII (1958): 133-140.

Karadžić Vuk. Srpski rječnik (1852). Sabrana dela Vuka Karadžića. Knj. 11. Beograd, 1986.

Knežević Srebrica, Jovanović Milka. „Jarmenovci“. SEZb. LXXIII. Beograd, 1958.

Machek Václav. Etymologický slovnik jazyka českého a slovenského. Praha, 1957.

Marjanović Vesna. „Komunikacija s tradicijom na primeru pogrebnog rituala u Šajkaškoj, Timočkoj krajini i pirotskom regionu“. Glasnik Etnografskog muzeja u Beogradu. 71 (2007): 63-78.

Milosavljević Sava. „Srpski narodni običaji iz sreza homoljskog“. SEZb. XIX. Beograd, 1914.

NDP 2012: Narodnaya demonologiya Poles'ya. T. 2. L. E. Vinogradova, E. E. Levkievskaya (sost.). Demonologizaciya umershih lyudej. M., 2012.

Nevskaya Lidiya. „Semanticheskaya struktura balto-slavyanskogo pogrebal'nogo prichitaniya“. Etnolingwistyka. Problemy jezyka i kultury. Bartminski J. (red.) 9/10 (1998): 51-66.

Nikolić Vladimir. „Iz Lužnice i Nišave“. SEZb. XVI. Beograd, 1910.

Nikolić Desanka. Gornje Dragačevo (Etnoloshko proučavanje kulturnih promena). Beograd. 1996.

PVL 1950: Povest' vremennyh let (po Lavrent'evskoj letopisi). 1377 g. M., L.

Petrović Aleksandar. „Gradja za izuchavanje naše narodne religije“. Glasnik Etnografskog muzeja и Beogradu. XIV (1939): 31-42. 
Petrović Atanasije. „Narodni zhivot i obichaji u Skopskoj Crnoj Gori“. SEZb. VII. Beograd, 1907.

Radenković Ljubinko. Simbolika sveta u narodnoj magiji Južnih Slovena. Beograd, 1996.

Radenkovich Lyubinko. „Nazvaniya demonov, vedushchie proiskhozhdenie ot detej, umershih do kreshcheniya u slavyan“. Balcanica. XXIV. Belgrade, 2014: 203-221.

Radenkovich Lyubinko. „Hodyachij pokojnik v duhovnoj kul'ture slavyan“. Alekseev A. A., Antropov N. P., itd (red). Slavische Geisteskultur: Ethnolinguistische und philologische Forschungen. T. 1. Slavyanskaya duhovnaya kul'tura: etnolingvisticheskie i filologicheskie issledovaniya. Ch. 1, Frankfurt am Main, 2016: 141-156.

RJAZU 1904-1910: Rječnik hrvatskoga ili srpskoga jezika. VI (lekenički-moračice), Zagreb, 1904-1910.

RSANU 1962: Rečnik srpskohrvatskog književnog i narodnog jezika (ur. M. Stevanović, M. Pavlović i dr.). Knj. II (Bogoljub - Vrazhogrnci). Beograd, 1962.

RSANU 1975: Rečnik srpskohrvatskog književnog i narodnog jezika (ur. M. Stevanović, M. Pešikan i dr.). Knj. IX (jurget-kolitva). Beograd, 1975.

RSANU 1984: Rečnik srpskohrvatskog književnog i narodnog jezika (ur. M. Pešikan, I. GrickatRadulović i dr.). Knj. XII (makvei-mozurica). Beograd, 1984.

RSANU 1988: Rečnik srpskohrvatskog književnog i narodnog jezika (ur. M. Pešikan, I. GrickatRadulović i dr.). Knj. XIII (moire-naklapusha). Beograd, 1988.

Schneeweis Edmund. Vjerovanja i običaji Srba i Hrvata. Zagreb, 2005.

Sedakova Ol'ga. Poetika obryada. M., 2004.

SEZb - Srpski etnografski zbornik. Beograd, 1894- .

Šehović Amela, Haverić Đenita. Leksika orijentalnog porijekla u frazemama bosanskog jezika. Sarajevo, 2017.

Škaljić Abdulah. Turcizmi u srpskohrvatskom jeziku. IV izdanje. Sarajevo, 1979.

Skok Petar. Etimologijski rječnik hrvatskoga ili srpskoga jezika. Knj. 2 (K-poni). Zagreb, 1972.

Sreznevskij Izmail I. Materialy dlya slovarya drevne-russkago yazyka. T. 1. 1893.

Sreznevskij Izmail I. Materialy dlya slovarya drevne-russkago yazyka. T. 2. 1902.

SRNG 2005: Slovar' russkih narodnyh govorov. Vyp 39. Sankt Peterburg, 2005.

SRYA 1983: Slovar' russkogo yazyka XI-XVII vv. (red. F. P. Filin). Vyp 10. M., 1983.

SRYA 1990: Slovar' russkogo yazyka XI-XVII vv. (red. G. A. Bogatova). Vyp 16. M., 1990.

SRYA 2002: Slovar' russkogo yazyka XI-XVII vv. (red. G. A. Bogatova). Vyp 26. M., 2002.

Stanić Milija. Uskočki rechnik. 1. Beograd. 1990.

Tolstaya Svetlana M. „K semanticheskoj rekonstrukcii slav. *vesel- i *rad-“. Furlan M., ŠivicDular A. (ur.). Praslovanska dialektizacija v luči etimoloških raziskav. Ob stoti obletnici rojstva akademika Franceta Bezlaja. Ljubljana, 2010: 257-264.

Tolstoj Nikita I., Tolstaya Svetlana M. „Slovo o obryadovom tekste (kul'turnaya semantika slav. *vesel-)“. Tolstoj N. I. (red.) Slavyanskoe yazykoznanie. Mezhdunarodnyj s'ezd slavistov. Bratislava, 1993. Doklad rossiskoj delegacii. M., 1993: 162-186.

Toporkov Andrej L. „Veselovskij kak issledovatel' 'Sisinievoj legendy'“. Goven'ko T. V. (red.). Nasledie Aleksandra Veselovskogo v mirovom kontekste: Issledovaniya i materialy. M., $\mathrm{SPb}, 2016: 263-282$.

Vakarelski Hristo. B'lgarski pogrebalni obichai. Sravnitelno izuchavane. Sofiya, 1990.

Veselovskij A. N. „Molitva sv. Sisiniya i Verzilovo kolo“. Zhurnal Ministerstva narodnogo presveshcheniya. 5 (1895): 226-234.

Vlasova Marina. Russkie sueveriya. Sankt-Peterburg, 2018.

Vrazhinovski Tanas. „Gradonosnite oblaci vo makedonskata narodna tradicija“. Etno-kulturoloshki zbornik. VII (2001/2002): 41-47.

Zhuravlev Anatolij. F. Yazyk i mif. Lingvisticheskij kommentarij k trudu A. N. Afanas'eva „Poeticheskie vozzreniya slavyan na prirodu”. M., 2005.

Zhujkova Margarita. „Nominaciya smerti i arhaicheskoe myshlenie“. Etnolingwistyka. 9/10 (1998): 67-80.

Zahariev Jordan. „Kyustendilsko krajshche“. Sbornik “za narodni umotvoreniya i narodopis”. Sofiya, 1918.

Zelenin Dmitrij K. „Tabu slov u narodov vostochnoj Evropy i severnoj Azii“. Sbornik Muzeya antropologii i etnografii. 9. Leningrad, 1929. 


\section{Dragana Djurić}

\section{TERMS FOR THE DECEASED AMONG SLAVIC PEOPLES}

\section{Summary}

Posthumous rituals among all the Slavic peoples feature archaism and a tendency not to change. If they are not properly carried out, it is believed that the deceased may return and harass their loved ones, or that from the other world they may in fact refuse assistance to their living descendants. Safeguards from the deceased included avoiding mentioning their given name, so as not to conjure them up, therefore different shared and "neutral" terms for the deceased were used.

The paper analyses different terms for the deceased among the Slavs. It starts with the analysis of the oldest recorded terms with the root $* m r-/ * m e r$ - and $* n a v-$, continues on to different regional terms. Next it analyses taboo terms, their motivation and function in posthumous rites and folk culture in general. The terms for the deceased who did not die of natural causes, but rather died in other ways (killed, suicide, hung, drowned) are grouped separately.

Key words: death, terms for the deceased, posthumous rites, Slavs. 